Vol. 17 (2008): 227-239.

\title{
Properties and cleanability of new and traditional surface materials in cattle barns - a field study
}

\author{
Risto Kuisma ${ }^{1}$, Hanna-Riitta Kymäläinen ${ }^{1}$, Maarit Hellstedt² ${ }^{2}$ Pekka Jauhiainen², Jenni Määttä ${ }^{1}$, \\ Anna-Maija Sjöberg ${ }^{1 *}$ \\ ${ }^{1}$ Department of Agrotechnology, PO Box 28, FI-00014 University of Helsinki, Finland \\ ${ }^{2}$ MTT Agrifood Research Finland, Animal Production Research, Vakolantie 55, FI-03400 Vihti, Finland \\ *e-mail: anna-maija.sjoberg@helsinki.fi
}

\begin{abstract}
In this study surface properties and cleanability of new and traditional surface materials in cattle barns were examined in a field test. The concrete and plastic-coated samples were placed on a walking path on the floor and on a feeding table in a cattle barn. The surfaces were characterized using colorimetric and gloss measurements and determination of topography. In most cases, the colour of the surfaces placed on the floor darkened during the one year study period, whereas the colour changes of the samples placed on the feeding table did not show a similar trend. However, in both locations the plastic-coated surfaces were generally the easiest to clean, and the highest colour changes indicating soil residues were detected on the uncoated and silane-impregnated concrete surfaces. The difference between the locations was also seen in the gloss values, which increased in the samples placed on the floor during the one-year test period but varied considerably between the different materials on the surfaces placed on the feeding table. This field study confirmed the observation from earlier laboratory studies that plastic coatings improved the cleanability of concrete cattle barn surfaces. Silane impregnation was not functionally competitive with the plastic coatings. In general, the cleanability results were in accordance with the results of previous laboratory experiments but the field study provided practical information about the behaviour of the surface materials examined.
\end{abstract}

Key-words: cleanability, cattle barn, flooring, colorimetric method, gloss, profilometry, SEM 
Kuisma, R. et al. Surface materials in cattle barns - a field study

\section{Introduction}

Material choices in agricultural environments affect animal welfare, hygienic condition of surfaces and products, and the working environment of the personnel. The durability and cleanability of surfaces are aspects affecting the choice of flooring material for cattle barns (Hörndahl 1995). The importance of this subject is emphasized in large animal buildings, which are nowadays common in many countries.

Concrete is a very generally used floor material in agricultural buildings. The floors of dairy cattle houses are almost exclusively made of concrete, because it can be textured to provide a slip-resistant, non-abrasive surface or finished with a smooth surface to aid drainage and cleaning (Barnes 1989). Although concrete is often very suitable for agricultural environments, it is affected by many environmental hazards, e.g. wear caused by animals and vehicles and chemical load caused by feeds, milk and manure (Nilsson 2005). Both chemical substances and mechanical impact on floorings cause corrosion and wear that may promote injuries to animals. In addition it may make cleaning difficult, thus promoting the spread of diseases (De Belie 1997, De Belie et al. 2000b). Therefore, the use of coatings to protect the surface of concrete against wear is of interest. Polyurethane is an example of materials which have been used in cattle barns and horse stables, but their use in animal floorings is not widespread (Kymäläinen et al. 2008). Recent material research has focused on searching for new materials with potential for use in animal houses. A floor surface which is too rough causes rapid wear of animal hooves and causes grazes on other parts of the body (De Belie 1997). Floors with an initially ideal surface may become too rough or slippery because of degradation (De Belie 1997). A summary of earlier studies concerning cleanability of different kinds of agricultural surfaces and methods is presented in Table 1 (Määttä 2007).

In our earlier laboratory studies, new surface materials for use in floors and feeding tables in cattle barns were developed. In these studies, surface properties and cleanability of several new and traditional surface materials were examined as new (Määttä et al. 2008a) and when chemically and mechanically worn (Määttä et al. 2008b). The materials examined were basic cement paste, both uncoated and treated with inorganic sealants or with fluorochemical coatings of concrete including epoxy, polyurethane, polyester and acrylic, and three different jointing materials.

There is some evidence from public office buildings that despite the fact that numerical results of laboratory experiments may not straightforward correlate with the values obtained from field experiments carried out in use conditions, materials can be compared and ranked according to both laboratory and field experiments (Kuisma et al. 2008).

The aim of the present study was to examine the surface properties and cleanabilities of new and traditional surface materials in a field test and to compare these results with the results of the earlier laboratory experiments (Määttä et al. 2008a,b). The surface material samples were selected to this study according to the results of the laboratory experiments and placed on a feeding table and walking path in a cattle barn. A colorimetric method was used for evaluating cleanability. The surface properties were examined by determining surface roughness parameters and gloss.

\section{Materials and methods}

\section{Laboratory-made and commercial surface materials}

The materials evaluated are presented in Tables 2 and 3. Epoxy, polyester, polyurethane, acrylic, substances containing oil, and plaster were used as surface coatings. In addition, asphalt and concrete without any coating or extra treatment were examined. The surface materials were selected to this study according to previous laboratory experiments (Määttä et al. 2008a), with exceptions as mentioned in Table 2. In all experimental materials, the basic concrete was laboratory-made, whereas commercial versions of the other materials were examined. However, not all 
Vol. 17 (2008): 227-239.

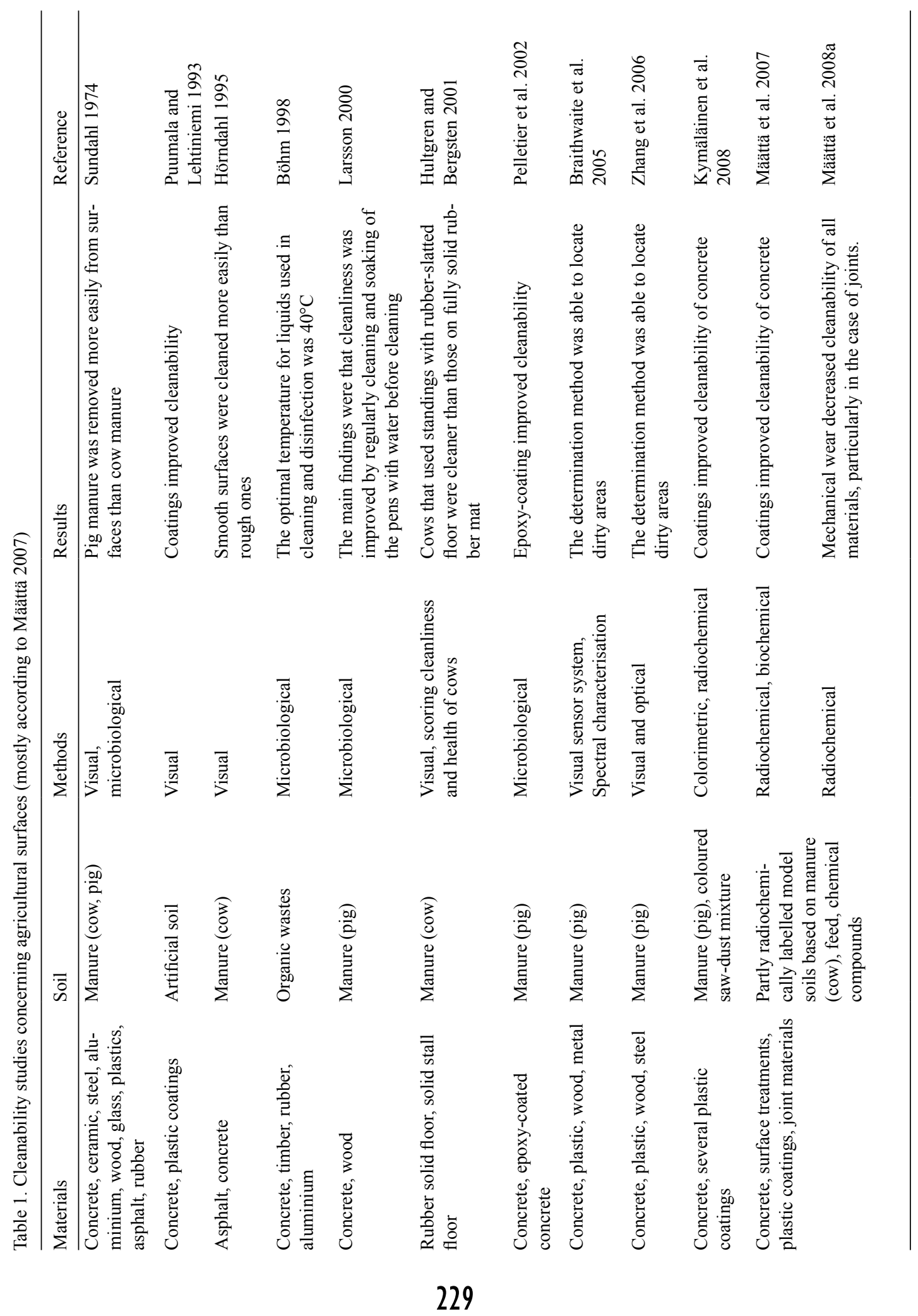




\section{AGRICULTURAL AND FOOD SCIENCE}

\section{Kuisma, R. et al. Surface materials in cattle barns - a field study}

Table 2. Codes and compositions of the evaluated surface materials and their use in the cattle barn in the study.

\begin{tabular}{|c|c|c|c|c|c|}
\hline \multirow{2}{*}{ Code } & \multicolumn{2}{|c|}{ Components } & \multirow{2}{*}{$\begin{array}{c}\text { Experimental material } \\
\text { (E) or material already } \\
\text { in use }(\mathrm{U})\end{array}$} & \multicolumn{2}{|r|}{ Site } \\
\hline & Substrate & Surface coating or treatment & & Floor & Feeding table \\
\hline $\mathrm{C} 1$ & Concrete & None & $\mathrm{U}$ & $\mathrm{X}$ & $\mathrm{X}$ \\
\hline $\mathrm{C} 2$ & Concrete & Plaster and silane & $\mathrm{E}$ & $\mathrm{X}$ & $\mathrm{X}$ \\
\hline Col & Concrete & Acrylic coating & $\mathrm{U}$ & $X$ & $\mathrm{X}$ \\
\hline $\mathrm{Co} 2$ & Concrete & Polyurethane coating & $\mathrm{U}$ & $X$ & $\mathrm{X}$ \\
\hline $\mathrm{Co} 3$ & Concrete & Epoxy coating & $\mathrm{U}$ & $X$ & $\mathrm{X}$ \\
\hline $\mathrm{Co} 4$ & Concrete & Polyester coating & $\mathrm{U}$ & - & $\mathrm{X}$ \\
\hline $\operatorname{Co5} *$ & Concrete & Oil based coating & $\mathrm{E}$ & $\mathrm{X}$ & - \\
\hline Co6* & Concrete & Oil based and rubbercoating & $\mathrm{E}$ & $\mathrm{X}$ & - \\
\hline
\end{tabular}

-not suitable

* Not included in the laboratory study.

Table 3. Manufacturing and formulation of substrates and surface coatings or treatments.

\begin{tabular}{|c|c|c|c|c|}
\hline \multirow[t]{3}{*}{ Code } & \multicolumn{4}{|c|}{ Manufacturing of components } \\
\hline & \multicolumn{2}{|r|}{ Substrate } & \multicolumn{2}{|c|}{ Surface coating or treatment } \\
\hline & Type & Manufacturing & Type & Manufacturing \\
\hline $\mathrm{C} 1$ & Concrete & $\begin{array}{l}\text { Components }\left(\mathrm{kg} \mathrm{m}^{-3}\right) \text { : Rapid cement } \\
\text { 333.6, sand } 1836.1 \text {, water } 183.5, \\
\text { VB-Parmix(=plasticizer) } 1.33 \text {. }\end{array}$ & Trowelled & - \\
\hline $\mathrm{C} 2$ & Concrete & See $\mathrm{Co} 3$ & $\begin{array}{l}\text { Cement-based coat- } \\
\text { ing }(7-10 \mathrm{~mm}) \text { and } \\
\text { silane treatment } \\
\text { (StoFinexter) }\end{array}$ & $\begin{array}{l}\text { StoCryl CP -primer+ StoCrete VM Hard- } \\
\text { cement based coating + StoCryl HP } 200 \\
\text {-hydrophobic impregnation (primer and im- } \\
\text { pregnation agent were applied by brushing, } \\
\text { coating was trowelled }\end{array}$ \\
\hline Col & Concrete & See Co3 & $\begin{array}{l}\text { Acrylic coating }(5-6 \\
\mathrm{mm})(\text { Nanten })\end{array}$ & $\begin{array}{l}\text { Primed with acryl; acryl DC } 305 \text {, Sand ad- } \\
\text { dition }\left(7 \mathrm{~kg} \mathrm{~m}^{-2} \text {, granule size } 0.6-1.2 \mathrm{~mm}\right)\end{array}$ \\
\hline $\mathrm{Co} 2$ & Concrete & See $\mathrm{Co} 3$ & $\begin{array}{l}\text { Polyurethane } \\
\text { coating }(3 \mathrm{~mm}) \\
\text { (Nanten) }\end{array}$ & $\begin{array}{l}\text { Primed with thinned PU } 710 \text { sand addition } \\
(0.5 \text { volume- } \% \text { of amount of polyurethane, } \\
\text { grain size } 1 \mathrm{~mm}) \text {, paint rolling of PU } 710\end{array}$ \\
\hline $\mathrm{Co} 3$ & Concrete & $\begin{array}{l}\text { Same composition as in } \mathrm{C} 1 \text {. Surface } \\
\text { was sand blasted and vacuum } \\
\text { cleaned before coating. }\end{array}$ & $\begin{array}{l}\text { Epoxy coating ( } 2 \\
\mathrm{~mm}) \text { (DeLaval) }\end{array}$ & $\begin{array}{l}\text { Mixture of transparent epoxy and sand ( } 3 \\
\left.\mathrm{~kg} \mathrm{~m}^{-2} \text {, granule size } 0-0.9 \mathrm{~mm}\right) \text {, spread } \\
\text { with a spatula }\end{array}$ \\
\hline $\mathrm{Co} 4$ & $\begin{array}{l}\text { Polyester } \\
\text { concrete }\end{array}$ & Prefabricated element & (DeLaval) & No information available \\
\hline Co5 & Concrete & See $\mathrm{Co} 3$ & $\begin{array}{l}\text { Oil-based SE } \\
\text { Biomassa }(1.4 \mathrm{~mm}) \\
\text { (Suomen Elektrodi) }\end{array}$ & $\begin{array}{l}\text { Priming with thinned SE Biomassa } \\
\text { (plastic:hardener }=50: 100) . \text { Coating with } \\
\text { SE Biomassa (plastic:hardener }=70: 100) \\
\text { Spreading of quartz granules }(0.8-1.2 \mathrm{~mm} \text { ) }\end{array}$ \\
\hline Co6 & Concrete & See $\mathrm{Co} 3$ & $\begin{array}{l}\text { Primer SE } \\
\text { Biomassa, coating } \\
\text { SE Biomassa and } \\
\text { rubber }(0.7 \mathrm{~mm}) \\
\text { (Suomen Elektrodi) }\end{array}$ & $\begin{array}{l}\text { Priming with thinned SE Biomassa } \\
\text { (plastic:hardener }=50: 100) . \text { Coating with } \\
\text { SE Biomassa (plastic:hardener }=70: 100) \\
\text { containing quartz grains }(0.2 \mathrm{~mm}) \text { and rub- } \\
\text { ber grains }(0.7 \mathrm{~mm})\end{array}$ \\
\hline
\end{tabular}

- no surface coating 
Vol. 17 (2008): 227-239.

the materials are used in animal houses or marketed for that use at present (Table 2). The coded samples as three replicates were placed in a metal frame in random order and fastened on the floor (sorting gate) and feeding table.

\section{Cleanability experiments and characterization of surfaces}

The experimental design of determination of cleanability and surface properties is presented in Fig. 1. Cleanability was examined using a colorimetric method. A similar method was also used in the study by Kymäläinen et al. (2008), which focused on flooring materials for use in piggeries. Surface properties were examined using a laser profilometer, a scanning electron microscope (SEM) and a gloss meter. The similar SEM measurements were carried out as in the earlier laboratory studies for the same surface materials as unused (Kymäläinen et al. 2008) and worn (Määttä et al. 2008b). Topography, colour and gloss of the samples were measured in situ at 3-month intervals between March 2006 and November 2007.

\section{Measurement of cleanability using the colorimetric method}

The cleaning efficiency was measured with a Minolta Chroma Meter CR-210 colorimeter (Minolta Co Ltd), equipped with Standard Illuminant D65 as described previously (Pesonen-Leinonen et al. 2003, Redsven et al. 2003). In this study the $L^{*}$ (lightness) value was used for assessing the soiling and cleaning properties of the plastic surfaces. Measurements were performed after the cleaning, which was made using running water and a scrubbing brush. The results were expressed as soil residues, calculated from the means of the $L^{*}$ values of the sample:

Soil residue $\Delta \mathrm{L} * \mathrm{R}=\mathrm{L} *$ unsoiled $-\mathrm{L} *$ cleaned

\section{Gloss measurements}

The gloss of plastic surfaces was measured using a three-angle glossmeter Picogloss 503. The main principle of this device is based on measuring the amount of reflected light directed to a surface at a specified angle from its normal. The amount of light reflected from the surface under investigation is divided by the amount of light reflected from the surface of a reference smooth black glass plate (de-

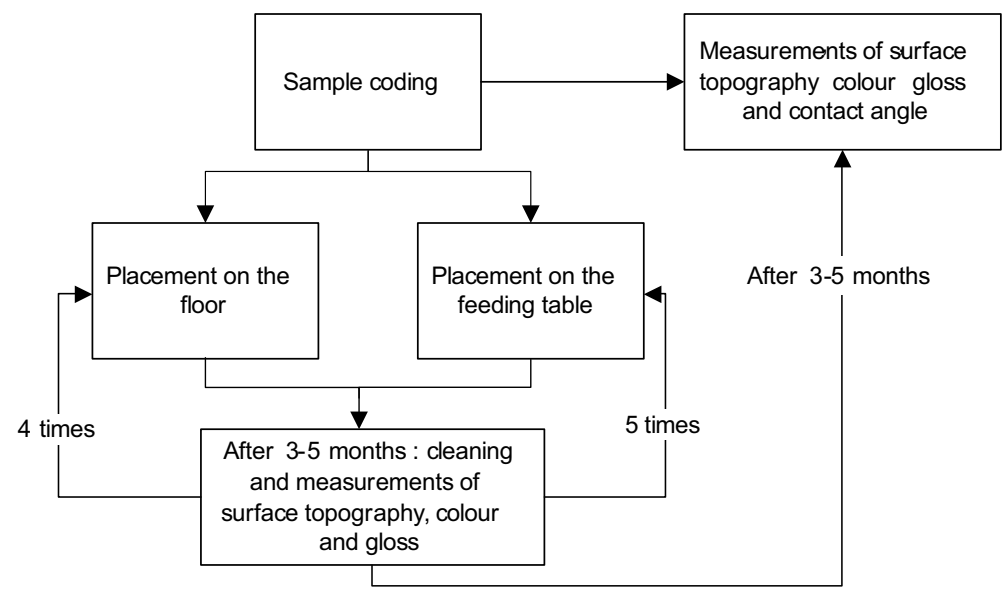

Fig.1. Experimental setup of the study: procedures and measurements in the cattle barn. 
Kuisma, R. et al. Surface materials in cattle barns - a field study

livered by the manufacturer of the glossmeter) and the specular gloss is obtained by multiplying this intensity ratio by 100 . The readings are expressed in $\mathrm{GU}$ (gloss units). All the measurements were carried out using an incidence angle of $85^{\circ}$. Measurements were performed after the cleaning.

\section{Topography assessment}

The roughness of new and worn surface materials was measured using a laser profilometer (MicroEpsilon ILD1400-100) by running it four times for $100 \mathrm{~mm}$ over the tested surfaces, varying the scan location. The data analysing method was the same as presented by Kymäläinen et al. (2008). The results are averages of all scans of the studied material as new and during the test (3, 6, 9 and 12 months). Change due to wear was calculated from the results of 9 months (floor) or 12 months (feeding table) of use. One image at each magnification was recorded and from each image five line profiles were measured. The high spot count (HSC) and peak average height values (Rpm) were derived from the line profiles. In addition, images of the surfaces were taken using a scanning electron microscope (JEOL JSM-840, USA) at $100 \times, 500 \times$ and $1500 \times$ magnifications. The magnification $500 \times$ illustrated the surface best and was used for each material.

\section{Results}

As can be seen in the colorimetrically determined soil residues in Fig. 2a, C1 (30-50\%), C2 (15-30\%) and $\mathrm{Co} 4(10-25 \%)$ showed the greatest colour changes, indicating soil residues on the feeding table.
Fig. 2a. Cleanability as soil residue of the surfaces placed on the feeding table as estimated by colorimetric methods. The results are expressed as means (columns) and standard errors of means ( \pm SE, bar) of five replicates. The codes of surfaces are presented in Table 3.

Fig. 2b. Cleanability as soil residue of the surfaces placed on the sorting gate on the floor as estimated by colorimetric methods. The results are expressed as means (columns) and standard errors of means ( \pm SE, bar) of five replicates. The codes of surfaces are presented in Table 3.
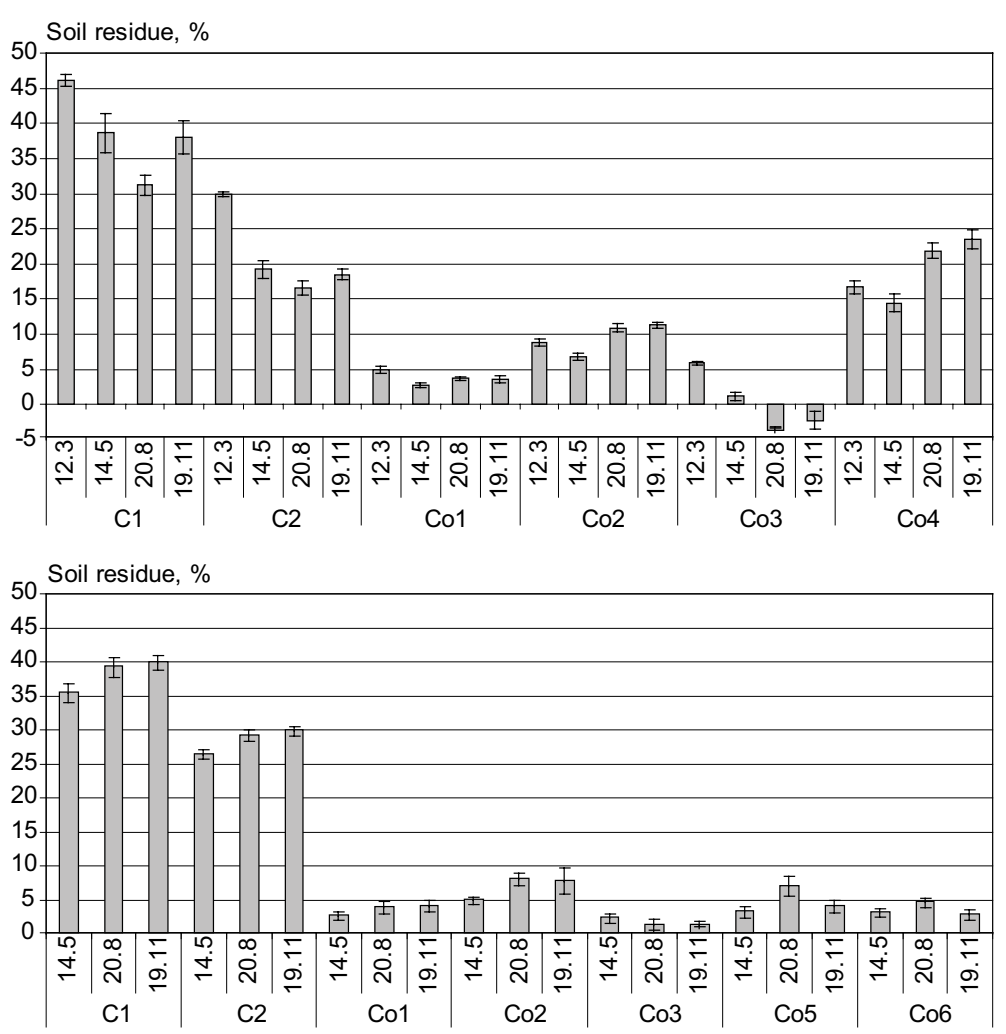
Vol. 17 (2008): 227-239.

Changes during the 12 month test period varied. Only a minor amount of soil, with soil residues below 5\%, was detected on $\mathrm{Co} 3$ and $\mathrm{Co} 1$ surfaces on the feeding table (Fig. 2a).

As in the case of the feeding table, the greatest soil residues on the flooring were detected on $\mathrm{C} 1$ (35-40\%) and $\mathrm{C} 2$ (25-30\%) (Fig. 2b). On the floor, $\mathrm{Co} 3, \mathrm{Co} 1$ and the $\mathrm{Co} 5$ had the lowest soil residues, below 5\%, and that of $\mathrm{Co} 2$ was not much greater $(<10 \%)$. Particularly on the $\mathrm{C} 1$ and $\mathrm{C} 2$ concrete samples, the soil residues had a slightly increasing trend during the 9 month test period.

In most cases the mean gloss of the surfaces placed on the floor increased during the one-year test period (Fig. 3b), whereas the gloss changes of the surfaces placed on the feeding table varied considerably between the different materials (Fig. 3a).
Surfaces of two replicate samples of the rubber-coated concrete (Co6) were totally worn out between 6 and 9 months of use. Wear caused varying changes in roughness for other floor and feeding table surfaces (Tables 4 and 5). In most cases the number of HSC increased on the feeding table, although the variation between the materials was great, from 5\% (acrylic coating) to over $800 \%$ (silane-impregnated concrete) (Table 4 ). The magnitude of changes was similar for the feeding table and floor samples, with the exception of $\mathrm{Co} 2$, on which HSC increased on the feeding table but decreased at the sorting gate. The effect of wear on surface roughness was lowest on the acrylic coating. Changes in the Rpm of the surfaces varied, and only weak correlation between HSC and Rpm was observed ( $r=0.424$ for all samples, statistically significant at the 0.01 level).
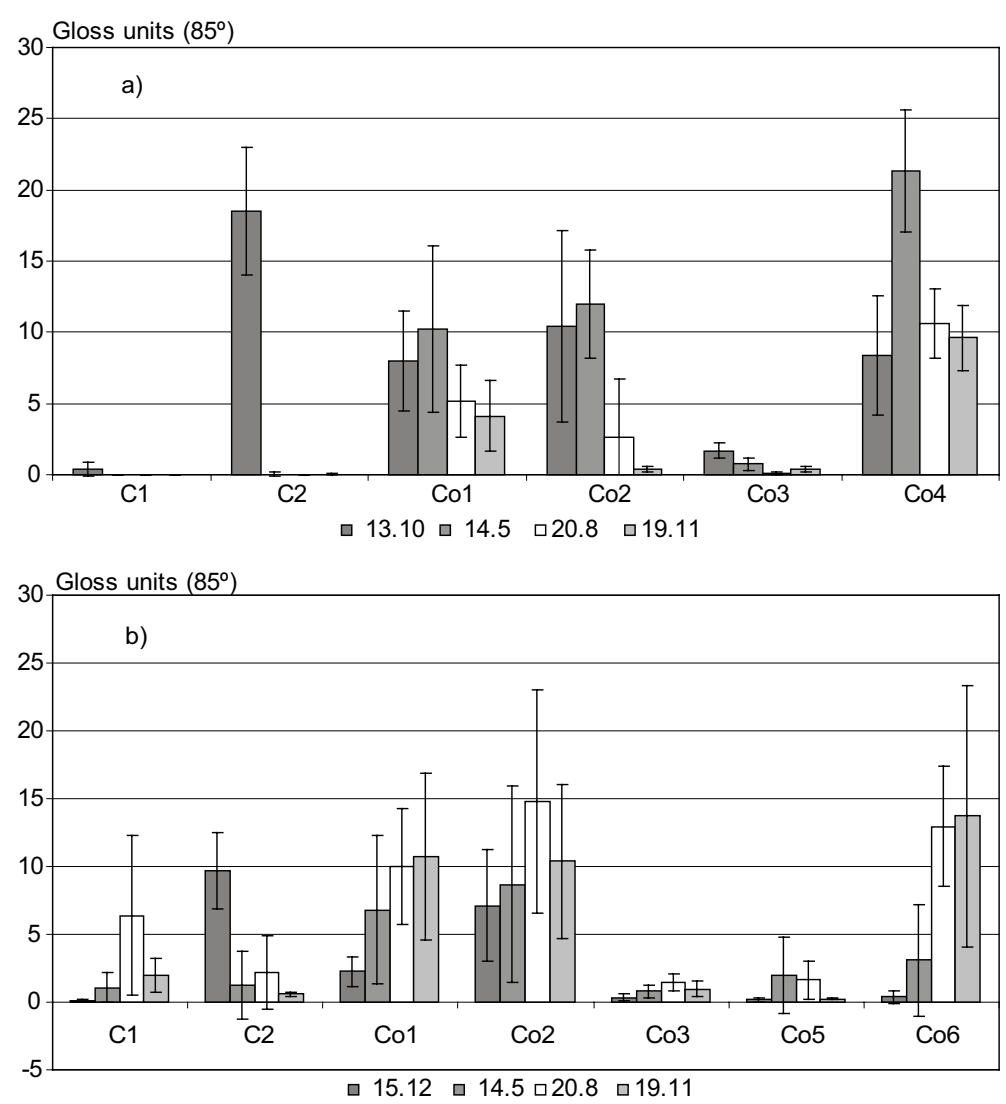

Fig. 3. Gloss of the samples placed on the feeding table (a) and on the floor (b). Results are means of the gloss values (as gloss units, $85^{\circ}$ measurement angle) of five measurements (column) and standard errors of means ( \pm SE, bar). The codes of surfaces are presented in Table 3. 
Kuisma, R. et al. Surface materials in cattle barns - a field study

Table 4. Mean roughness of new and used surface materials on the feeding table. The codes of surfaces are presented in Table 3.

\begin{tabular}{lccccccc}
\hline Code & \multicolumn{3}{c}{ High spot count per $100 \mathrm{~mm}$} & & \multicolumn{3}{c}{ Peak average height, mm } \\
\cline { 2 - 4 } \cline { 6 - 7 } & New & $\begin{array}{c}12 \text { months } \\
\text { in use }\end{array}$ & $\begin{array}{c}\text { Change due to use for } 12 \\
\text { months, } \%\end{array}$ & & New & $\begin{array}{c}12 \text { months } \\
\text { in use }\end{array}$ & $\begin{array}{c}\text { Change due to use for } 12 \\
\text { months, } \%\end{array}$ \\
\hline C1 & 8.8 & 26.8 & 206 & & 0.3 & 0.4 & 43 \\
C2 & 1.3 & 12.0 & 856 & & 0.2 & 0.4 & 86 \\
Co1 & 22.3 & 23.5 & 5 & 0.4 & 0.4 & -1 \\
Co2 & 11.2 & 13.3 & 19 & 0.6 & 0.4 & -38 \\
Co3 & 54.2 & 38.0 & -30 & & 0.6 & 0.4 & -29 \\
Co4 & 1.4 & 7.0 & 400 & 0.4 & 0.4 & 1 \\
\hline
\end{tabular}

Table 5. Mean roughness of new and used floor materials at the sorting gate. The codes of surfaces are presented in Table 3.

\begin{tabular}{lcccccc}
\hline Code & \multicolumn{3}{c}{ High spot count per 100 mm } & \multicolumn{3}{c}{ Peak average height, mm } \\
\cline { 2 - 7 } & New & $\begin{array}{c}9 \text { months } \\
\text { in use }\end{array}$ & $\begin{array}{c}\text { Change due to use for } 9 \\
\text { months, } \%\end{array}$ & New & $\begin{array}{c}9 \text { months } \\
\text { in use }\end{array}$ & $\begin{array}{c}\text { Change due to use for } 9 \\
\text { months, } \%\end{array}$ \\
\hline C1 & 4.5 & 9.1 & 100 & 0.2 & 0.3 & 31 \\
C2 & 0.2 & 4.5 & 1808 & 0.1 & 0.1 & 75 \\
Co1 & 17.3 & 17.9 & 4 & 0.4 & 0.4 & -18 \\
Co2 & 10.7 & 4.1 & -62 & 0.6 & 0.2 & -71 \\
Co3 & 34.4 & 15.4 & -55 & 0.6 & 0.3 & -49 \\
Co5 & 3.7 & 11.2 & 206 & 0.3 & 0.1 & -58 \\
Co6 & 26.3 & 20.9 & -20 & 0.4 & 0.6 & 61 \\
\hline
\end{tabular}

${ }^{1}$ From two test pieces the surface treatment had worn out between the measurement of 6 months and 9 months in use. For these materials, the numeric results are for 3 (or 5) replicate samples.

Qualitative SEM micrographs of different types of feeding table and sorting gate floor surface materials are presented in Fig. $4 \mathrm{a}$ and $4 \mathrm{~b}$. The most typical images were selected from the replicate measurements of magnification at $500 \times$. When compared with the new surfaces (Määttä et al. 2008a), clear changes due to wear were observed on all surfaces (Fig. 4a and 4b). As new the plastic coatings (Co1-Co4) were among the smoothest surfaces (Määttä et al. 2008b), but after wearing only the acrylic coating (Co1) on the floorings and acrylic and polyurethane (Co2) coatings on the feeding table were ranked as smooth (Fig. $4 b$ ) according to the SEM pictures. There were some differences between the effect of wear in the two locations: $\mathrm{Co} 2$ was worn more on the flooring than on 


\section{AGRICULTURAL AND FOOD SCIENCE}

Vol. 17 (2008): 227-239.

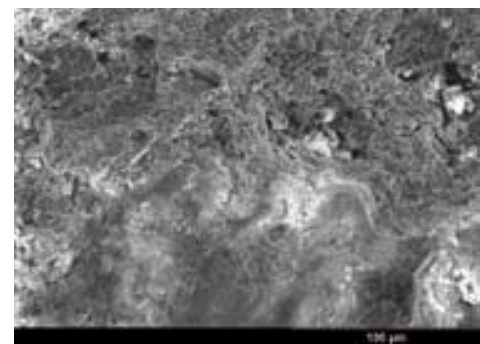

a) Concrete, trowelled (C1)

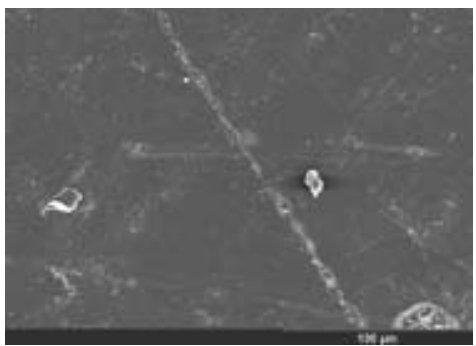

d) Concrete, polyurethane coating (Co2)

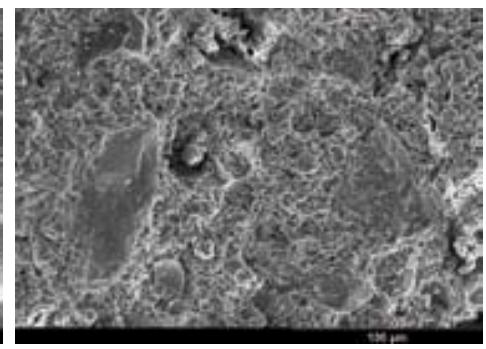

b) Concrete, cement d coating (C2)

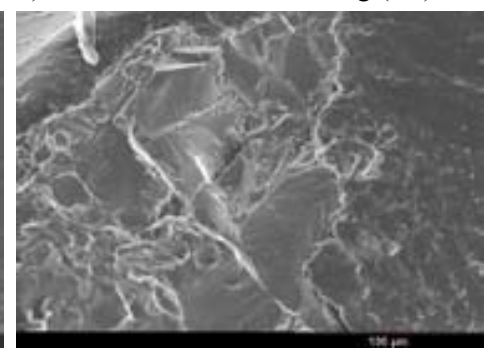

e) Concrete, epoxy coating (Co3)

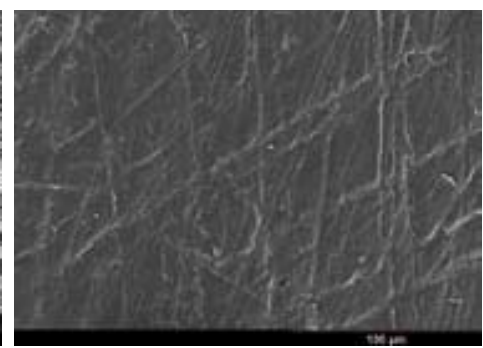

c) Concrete, acrylic coating (Co1)

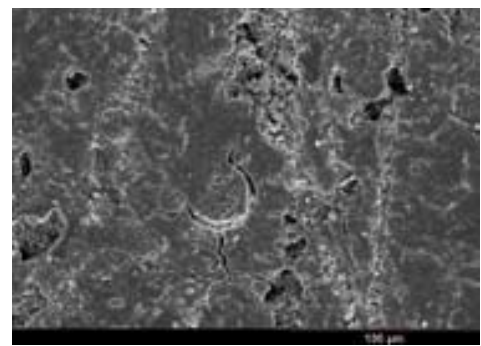

f) Polyester concrete (Co4)

Fig. 4a. SEM micrographs of the mechanically worn surface materials on the feeding table (a-f), magnification $500 \times$. The codes of surface materials are given in Table 3 .

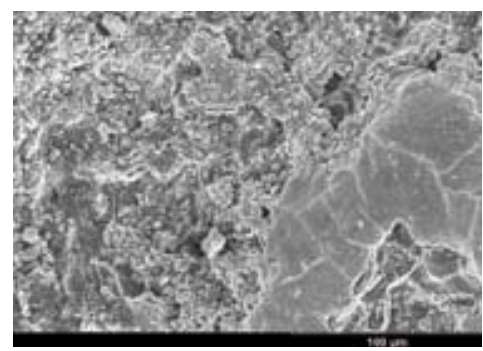

a) Concrete, cement based coating (C2)

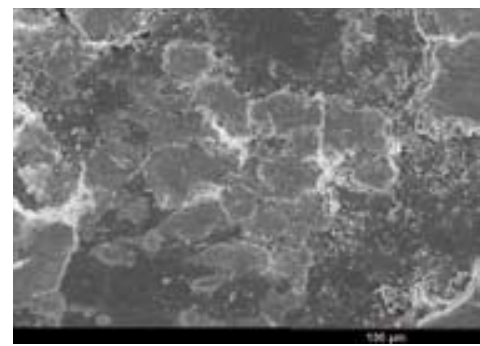

d) Concrete, epoxy coating (Co3)

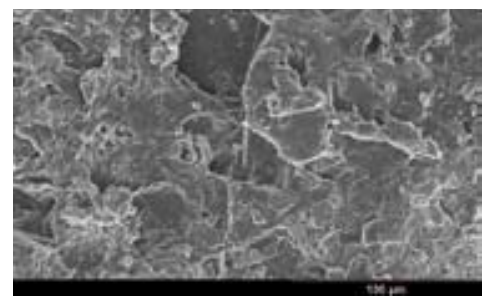

g) Concrete, oil-based SE biomassa (Co6)

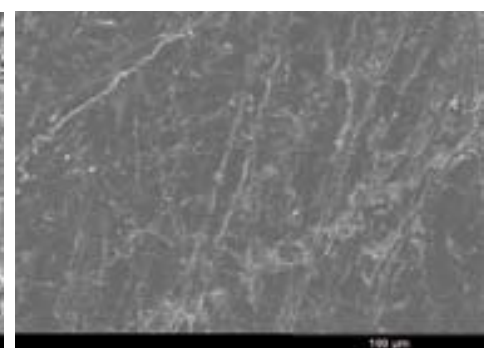

b) Concrete, acrylic coating (Co1)

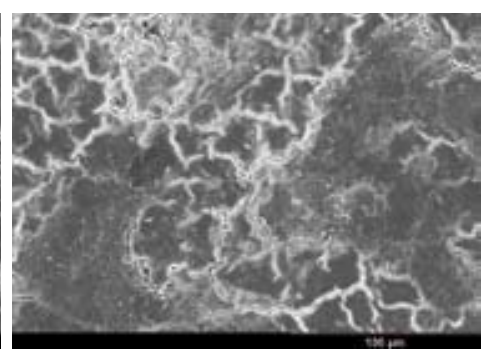

e) Concrete, trowelled (Co4)

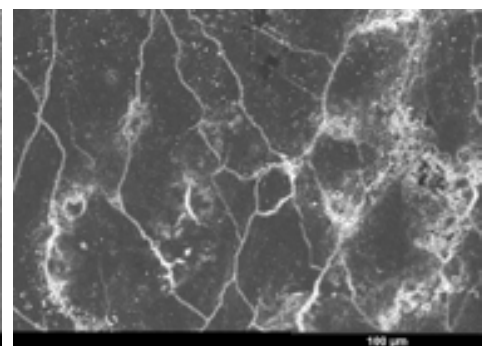

c) Concrete, polyurethane coating (Co2)

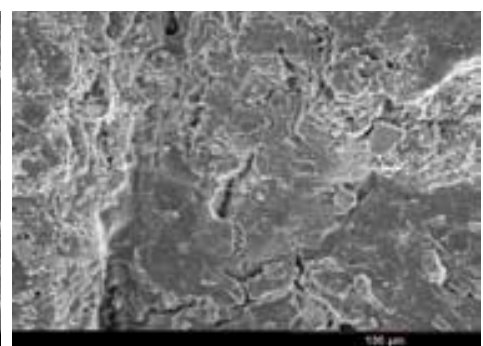

f) Concrete, primer SE biomassa (Co5)

Fig. 4b. SEM micrographs of the mechanically worn surface materials on the sorting gate on the floor (a-g), magnification $500 \times$. The codes of surface materials are given in Table 3. 
Kuisma, R. et al. Surface materials in cattle barns - a field study

the feeding table, whereas in the case of $\mathrm{Co} 3$ and Co1 no clear differences in the SEM figures taken from the two locations were observed. Changes were also observed on the surfaces $\mathrm{C} 1$ and $\mathrm{C} 2$, but it is difficult to say how much these were caused by wear and how much by the absorption of soil into the surface.

\section{Discussion}

Soil residue has been considered to be the most valuable parameter calculated from the $\mathrm{L}^{*}$-value because it indicates whether the surfaces can be cleaned easily and economically. The surface colour offers an easy way to compare the cleanability of agricultural surfaces, but does not necessarily correlate with the absolute amount of soil attached to the surfaces. Cleanability of agricultural surfaces has earlier been examined with radiochemical methods in the laboratory (Kymäläinen et al. 2008, Määttä et al. 2008a). Measuring the amount of soil on the surface with radiochemical methods would provide quantitative information useful for studying different cleanability performances. However, in field studies it is not possible to use radiochemical methods and colorimetric method was a promising alternative.

The soil residue results show that in general the best cleaned surfaces were the plastic coatings. This is in accordance with previous studies by Puumala \& Lehtiniemi (1993), Kymäläinen et al. (2008) and Määttä et al. (2008a). Most of the best cleaned surfaces in this study were non-porous, in contrast to the uncoated and silane-impregnated concrete. On the feeding table polyester (Co4) coating could not be kept as clean as the other plastic coatings. This difference can be seen in the SEM pictures, showing that the $\mathrm{Co} 4$ coating was more porous than the other plastic coatings. Considering the other materials, the differences in cleanability could be explained by differences in their roughness observed from the SEM pictures but could not be explained by the HSC and Rpm roughness parameters. In our previous study the contact angles of uncoated con- cretes were low or even unmeasurable due to porosity or brittleness of the materials (Määttä et al. 2008a). According to these results the differences in cleanability of surfaces may be partly explained by the absorptivity or repellency of the surface to soil. Furthermore, coatings sealed and smoothened surfaces thus improving their cleanability.

The average peak height (Rpm) of the trowelled concrete $(\mathrm{C} 1)$ and polyurethane coating $(\mathrm{Co} 2)$ measured from new surface is in accordance with those measured in the study by Norring et al. (2006). Surface properties of new and worn floors in production buildings have earlier been studied with profilometric measurements by Kymäläinen et al. (2008). The artificial wear induced in that study was very mild. Therefore comparison between the two sets of results is rather difficult. However, Rpm of epoxy (Co3) and polyurethane (Co2) coatings both on the feeding table and on the sorting gate decreased similarly in both locations.

It is evident that consideration of the durability of building materials and components is an important aspect of design (De Belie et al. 2000a). In this study the laboratory experiments prior to the field test for pre-selecting surfaces to resist mechanical and chemical wear were shown to be valuable. Table 6 shows the order of superiority of the surface materials according to the colorimetric results in this study and to the radiochemical results from the previous laboratory studies (Määttä et al. 2008a,b). It can be seen that the results showed similarity between the laboratory and field experiments. Accordingly, when the materials were ranked in order of superiority according to the soil residues, the order was exactly the same according to both the feeding table and sorting gate floor surfaces (Table 6). In a comparison of colorimetric results in nonagricultural buildings it was similarly observed that plastic flooring materials could be ranked in the same order according to both laboratory and field experiments (Kuisma et al. 2008). However, the wear, soiling and cleanability methods differed from the methods used in the present study.

Similar changes in colour and gloss were observed on the flooring, but not on the feeding table. This could be explained by the dominating role of manure soil in the colour measurements on the 
Vol. 17 (2008): 227-239.

Table 6. Cleanability of the surface materials listed in order of superiority according to the colorimetric soil residues in the present field study $(\mathrm{C})$ and previous radiochemical laboratory studies (R) (based on sums of all radiochemical soils, Määttä et al. 2008a,b). The smaller the number, the better the cleanability. Only the five materials that were included in all three studies are ranked here. The codes of surfaces are presented in Table 3 .

\begin{tabular}{|c|c|c|c|c|c|}
\hline \multirow[t]{4}{*}{ Code } & \multicolumn{5}{|c|}{ Surface and detection method } \\
\hline & \multirow{3}{*}{ New } & \multicolumn{2}{|c|}{ Laboratory studies (R) } & \multicolumn{2}{|c|}{ Field study (C) } \\
\hline & & \multicolumn{2}{|c|}{ Worn in laboratory } & \multicolumn{2}{|c|}{ After 1-year field test } \\
\hline & & Chemical & Mechanical & Feeding table & Floor \\
\hline Col & 1 & 1 & 1 & 2 & 2 \\
\hline $\mathrm{Co} 2$ & 2 & 1 & 3 & 3 & 3 \\
\hline $\mathrm{Co} 3$ & 2 & 3 & 2 & 1 & 1 \\
\hline $\mathrm{C} 1$ & 5 & 4 & broken & 5 & 5 \\
\hline $\mathrm{C} 2$ & 4 & - & - & 4 & 4 \\
\hline
\end{tabular}

- Not included in the laboratory study.

flooring, whereas components on the feeding table are less colourful. Chemical loads and wearing were different in the two locations: wear at the sorting gate due to manure and cow claws was more intensive than that at the feeding table caused by fodder and cows licking the surface. Manure contains organic acids (acetic, propionic, lactic etc.), which constitute a severe chemical challenge to the concrete of agricultural structures (Berton et al. 2005). The quality of the concrete used in the floor can be selected to offer the best resistance to organic acids and aggressive conditions (Barnes 1989).

Material selection including corrosion-resistant materials and surface coatings is one means of preventing the formation of biofilms and extending the life-span of barn structures. Other parameters include designing against corrosion and control of aggressive environments (De Belie et al. 2000b). In this study the main focus was on cleanability, but depending on location thermal comfort, softness, friction, abrasiveness, surface profile and contact pressure should also be considered in material selection. However, floors which are hard to clean encourage the transmission of diseases in floors in animal buildings (De Belie et al. 2000c) and cleanability is thus one important factor determin- ing the hygienic properties of surfaces in cattle barns.

\section{Conclusions}

This field study confirmed the observation from earlier laboratory studies that plastic coatings improved the cleanability of concrete cattle barn surfaces. Silane impregnation was not functionally competitive with the plastic coatings. The materials were ranked in the same order of superiority acccording to the colorimetric results in this field study and radiochemical results from previous laboratory studies. The field study provided practical information about the behaviour of the surface materials examined.

Acknowledgements: Financial support from the Ministry of Agriculture and Forestry in Finland (project Easy-to-clean surfaces in farm buildings) and the Finnish Cultural Foundation is gratefully acknowledged. DeLaval, Nanten, Suomen Elektrodi and Lujabetoni are acknowledged for providing surface materials. We are grateful to Lippo Sundberg for help in practical work with the samples and measurements and for fruitful discussion during the study. 


\section{AGRICULTURAL AND FOOD SCIENCE}

Kuisma, R. et al. Surface materials in cattle barns - a field study

\section{References}

Barnes, M.M. 1989. Update on dairy cow housing with particular reference to flooring. British Veterinary Journal 145: 436-445.

Berton, A., Duchesne, J. \& Escadeillas, G. 2005. Attack of cement pastes exposed to organic acids in manure. Cement \& Concrete Composites 27: 898-909.

Braithwaite, I., Blanke, M., Zhang, G-Q. \& Carstensen, J. 2005. Design of a visionbased sensor for autonomous pig house cleaning. Journal on Applied Signal Processing 13: 2005-2017.

Böhm, R. 1998. Disinfection and hygiene in the veterinary field and disinfection of animal houses and transport vehicles. International Biodeterioration \& Biodegradation 41: 217-224.

De Belie, N. 1997. A survey on concrete floors in pig houses and their degration. Journal of Agricultural Engineering research 66: 151-156.

De Belie, N., Lenehan, J.J., Braam, C.R., Svennerstedt, B., Richardson, M. \& Sonck, B. 2000a. Durability of building materials and components in the agricultural environment, Part III: Concrete structures. Journal of Agricultural Engineering Research 75: 3-16.

De Belie, N., Richardson, M., Braam, C.R., Svennerstedt, B., Lenehan, J.J. \& Sonck, B. 2000b. Durability of building materials and components in the agricultural environment, Part I: The agricultural environment and timber structures. Journal of Agricultural Engineering Research 75: 225-241.

De Belie, N., Sonck, B., Braam, C. R., Lenehan, J. J., Svennerstedt, B. \& Richardson, M. 2000c. Durability of Building Materials and Components in the Agricultural Environment, Part II: Metal Structures. Journal of Agricultural Engineering Research 75: 333-347.

Hultgren, J. \& Bergsten, C. 2001. Effects of a rubber-slatted flooring system on cleanliness and foot health in tied dairy cows. Preventive Veterinary Medicine 52: 75-89.

Hörndahl, T. 1995. Slitstyrka och halksäkerhet hos golv $i$ djurstallar, Inverkan av material och utförande. (Wearing quality and prevention of slipperiness on solid floors in animal houses. Influence of materials and performance). Specialmeddelande 220, Sveriges Lantbruksuniversitet, Institutionen för Jordbrukets Biosystem och Teknologi, Lund, Sweden. 49 p. (in Swedish).

Kuisma, R., Kymäläinen, H.-R. \& Sjöberg, A.-M. 2008. Determination of cleanability and wearing of plastic flooring surfaces in field and laboratory conditions. Construction and Building Materials. In Press.

Kymäläinen, H.-R., Määttä, J., Joutsen, B.-L., Puumala, M., Kaustell, K. \& Sjöberg, A.-M. 2008. Effect of coating on cleanability of concrete as flooring material in piggeries. Biosystems Engineering 99: 88-98.

Larsson, K. 2000. Rengöring av svinstall. (Cleaning of pig-houses) JTI-rapport Lantbruk \& Industri Nr 266,
Jordbrukstekniska institutet, Uppsala, Sweden. 49 p. (in Swedish)

Määttä, J. 2007. Modifications of surface materials and their effects on cleanability as studied by radiochemical methods. MMTEK-Publications 26. Department of Agrotechnology, University of Helsinki, Finland. Yliopistopaino. $61 \mathrm{p}$.

Määttä, J., Kymäläinen, H.-R., Hellstedt, M., Mahlberg, R., Kuisma, R., Salparanta, L., Löija, M., Talibachew, A., Hurme, K.-R., Uusi-Rauva, A., Ritschkoff, A.-R. \& Sjöberg, A.-M. 2008a. Properties and cleanability of new and traditional surface materials in cattle barns. Agricultural and Food Science 17: 210-226.

Määttä, J., Hellstedt, M., Kuisma, R., Kymäläinen, H.-R., Mahlberg, R. \& Sjöberg, A.-M. 2008b. Effects of chemical and mechanical wearing on cleanability and surface properties of traditional and new surface materials in cattle barns - a laboratory study. Submitted.

Nilsson, C. 2005. Use of concrete for floors in livestock buildings. In: Concrete for a suitable agriculture, Agroaqua and community applications. Proceedings of the Vth International Symposium on 5-8 June 2005. San Lorenzo de El Escorial, Spain. p. 25-32.

Norring, M., Valros, A., Munksgaard, L., Puumala, M. Kaustell, K. O. \& Saloniemi, H. 2006. The development of skin, claw and teat lesions in sows and piglets in farrowing crates with two concrete flooring materials. Acta agriculturae Scandinavica. Section A Animal Science 56: 148-154.

Pelletier, F., DeFoy, C., Marquis, A., Godbout, S., Joncas, R., Gagné, R. \& Massé, D. 2002. Effects of different concrete types on gas, odour emissions and sanitation of swine buildings. In: Concrete for a suitable agriculture, Agro- aqua and community applications. Proceedings of the IVth International Symposium 21-24 April 2002. Ghent, Belgium. p. 287-294.

Pesonen-Leinonen, E., Redsven, I., Kuisma, R., Hautala, M. \& Sjöberg, A.-M. 2003. Cleaning efficiencies of mop cloths on floor coverings. Tenside Surfactants Detergents 40: 80-86.

Puumala, M. \& Lehtiniemi, T. 1993. Betonit ja muovit navetan lattiamateriaaleina. (Concrete and plastic as floor materials in barns) Vakolan tutkimusselostus 67, MTT, Vihti, Finland. 85 p. (in Finnish with English abstract)

Redsven, I., Kuisma R, Laitala, L., Pesonen-Leinonen, E., Mahlberg, R., Kymäläinen, H.-R., Hautala, M. \& Sjöberg, A.-M. 2003. An application of a standard proposal for testing soiling and cleanability of resilient floor coverings. Tenside Surfactants Detergents 40: 346-352.

Sundahl, A.-M. 1974. Byggnadsmaterial i djurstallar, Nedsmutsing - rengöring. (Building materials in animal houses, Soiling-cleaning). Sveriges Lantbruksuniversitet, Inst. för landbrukets byggnadsteknik, Aktuellt 211,Teknik, Uppsala, Sweden. 33 p. (in Swedish)

Zhang, G., Strøm, J.S., Blanke, M. \& Braithwaite, I. 2006. Spectral signatures of surface materials in pig buildings. Biosystems Engineering 94: 495-504. 
Vol. 17 (2008): 227-239.

\title{
SELOSTUS
}

\section{Uusien ja perinteisten pintamateriaalien ominaisuudet ja puhdistettavuus navetassa - kenttätutkimus}

\author{
Risto Kuisma, Hanna-Riitta Kymäläinen, Maarit Hellstedt, Pekka Jauhiainen, Jenni Määttä, \\ Anna-Maija Sjöberg \\ Helsingin Yliopisto ja MTT
}

Tutkimuksen tavoitteena oli selvittää uusien ja perinteisten pintamateriaalien pintaominaisuuksien vaikutus niiden puhdistuvuuteen kenttäolosuhteissa navetassa. Betoniset ja muovipinnoitetut näytteet sijoitettiin navetan ruokintapöytään sekä lattiaan kulkuväylälle, lähelle lypsyrobottia. Pintojen ominaisuuksista selvitettiin väri, kiilto sekä topografia. Suurin osa lattialle sijoitetuista pinnoista tummui vuoden koejakson aikana, kun taas ruokintapöydälle sijoitetuissa näytteissä ei havaittu samanlaista muutosta. Molemmissa koepaikoissa muovipinnoitetut pinnat olivat yleisesti ottaen helpoimmin puhdistettavia kuin pinnoittamattomat näytteet. Suurimmat värinmuutokset havaittiin pinnoittamattomissa ja silaanilla kyllästetyissä betonipinnoissa. Koepaikkojen välinen ero havaittiin myös kiiltoarvoissa: lattialle si- joitettujen näytteiden kiiltoarvot kasvoivat vuoden koeajanjakson aikana, kun taas ruokintapöydälle sijoitettujen näytteiden kiiltoarvot vaihtelivat eri materiaalien välillä huomattavasti. Tämä kenttätutkimus vahvisti aikaisemmissa laboratoriotutkimuksissa tehdyt havainnot, että muovipinnoitteet parantavat betonin puhdistettavuutta navettojen pintamateriaaleina. Silaanilla kyllästetty pinta ei ollut tässä tutkimuksessa toiminnallisesti kilpailukykyinen muovipinnoitteiden kanssa. Yleisesti ottaen tämän tutkimuksen puhdistuvuustulokset olivat samansuuntaiset kuin aikaisempien laboratoriossa tehtyjen kokeiden tulokset. Kenttätutkimus antoi kuitenkin tietoa tutkittujen pintamateriaalien käyttäytymisestä käytännön olosuhteissa navetassa. 